\title{
Ex-ante greenhouse gas balance of agriculture and forestry development programs
}

\author{
Martial Bernoux ${ }^{1 *}$; Giacomo Branca ${ }^{2}$; Aude Carro ${ }^{3}$; Leslie Lipper²; Garry Smith ${ }^{3}$; Louis \\ Bockel $^{4}$ \\ ${ }^{1}$ Institut de Recherche pour le Développement - IRD, UMR EcoESols "Functional Ecology \& Soil Biogeochemistry" \\ (INRA-IRD-SupAgro), Bat. 12, 2 Place Viala, 34060 - Montpellier Cedex 1 - France. \\ ${ }^{2}$ Food and Agriculture Organization of the UN (FAO), Agricultural Development Economics Division, Via \\ delle terme di Caracalla 00153 - Rome - Italy. \\ ${ }^{3}$ Food and Agriculture Organization of the UN (FAO), Investment Centre Division. \\ ${ }^{4}$ Food and Agriculture Organization of the UN (FAO), Policy Assistance and Resources Mobilization Division \\ "Corresponding author <martial.bernoux@ird.fr>
}

ABSTRACT: EX-ACT (EX-Ante Carbon-balance Tool) is a tool developed by the Food and Agriculture Organization of the United Nations (FAO). It provides ex-ante measurements of the mitigation impact of agriculture and forestry development projects, estimating net C balance from GHG emissions and Carbon (C) sequestration. EX-ACT is a land-based accounting system, measuring $\mathrm{C}$ stocks, stock changes per unit of

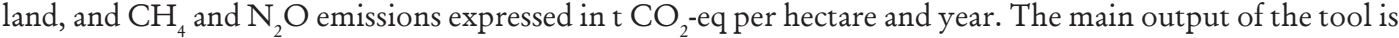
an estimation of the $\mathrm{C}$-balance associated with the adoption of improved land management options, as compared with a "business as usual" scenario. EX-ACT has been developed using primarily the IPCC 2006 Guidelines for National Greenhouse Gas Inventories, complemented by other existing methodologies and reviews of default coefficients. Default values for mitigation options in the agriculture sector are mostly from the $4^{\text {th }}$ Assessment Report of IPCC (2007). Thus, EX-ACT allows for the carbon-balance appraisal of new investment programmes by ensuring an appropriate method available for donors and planning officers, project designers, and decision makers within agriculture and forestry sectors in developing countries. The tool can also help to identify the mitigation impacts of various investment project options, and thus provide an additional criterion for consideration in project selection.

Key words: mitigation, nitrous oxide, methane, $\mathrm{C}$ sequestration, land use change and forestry

\section{Balanço ex-ante dos gases do efeito estufa nos programas de desenvolvimento na agricultura e em florestas}

RESUMO: EX-ACT (Ex-Ante Carbon-balance Tool, ferramenta para o balanço ex-ante de Carbono) é desenvolvida pela Organização das Nações Unidas para Agricultura e Alimentação (FAO). Tem como finalidade de fornecer estimativas ex-ante do impacto de atenuação na agricultura e nos projetos de desenvolvimento florestal, estimando o saldo líquido das emissões dos gases do efeito estufa (GEE) e do seqüestro de carbono (C). EX-ACT é um sistema de contabilidade que considera o uso da terra, medindo estoques de $\mathrm{C}$, mudanças do estoque por unidade de área, e emissões de $\mathrm{CH}_{4}$ e $\mathrm{N}_{2} \mathrm{O}$ expressos em $\mathrm{CO}_{2}$-eq por hectare e por ano. $\mathrm{O}$ resultado principal da ferramenta é uma estimativa do balanço de $\mathrm{CO}_{2}$-eq associados à adoção de opções de melhoria do manejo da terra, em comparação com um cenário chamado de "business as usual". EX-ACT foi desenvolvida usando principalmente as recomendações de 1996 para estabelecer os inventários nacionais de GEE (Guidelines for National Greenhouse Gas Inventories - IPCC, 2006) complementada por outras metodologias existentes e coeficientes padrão especificos quando disponíveis. Os valores padrão para as opções de mitigação no setor agrícola são na sua maioria provenientes do $4^{\circ}$ Relatório de Avaliação do IPCC (2007). Assim, EX-ACT estima o balanço de $\mathrm{C}$ dos novos programas de investimentos, garantindo um método adequado e disponível para financiadores e agentes de planejamento, projetistas, e governantes para os setores da agricultura e da silvicultura nos países em desenvolvimento. A ferramenta também pode ajudar a identificar os impactos de atenuação de opções possíveis em vários projetos de investimento, e assim fornecer um critério adicional para escolhê-las como parte dos projetos.

Palavras-chave: mitigação, óxido nitroso, metano, sequestro de carbono, mudança no uso da terra e florestas

\section{Introduction}

Agriculture and forestry sectors are of key concern in meeting climate change challenges, both as a source the problem and potentially as a solution. These sectors are responsible for a significant share of greenhouse gas
(GHG) emissions and, at the same time, they could potentially play an important role in climate change mitigation. The agricultural sector alone is responsible for about $14 \%$ of total global anthropogenic GHGs emissions (UNFCCC, 2008) and is expected to have high emission growth rates, driven mainly by population and

Sci. Agric. (Piracicaba, Braz.), v.67, n.1,p.31-40, January/February 2010 
income increases. Agriculture provides the primary source of livelihood for more than one third of the world's total workforce (UNFCCC, 2008). In the heavily populated countries of Asia and the Pacific, up to half of the population works in the agriculture sector, while two thirds of the working populations in subSaharan Africa make their living from agriculture (FAO, 2009a; ILO, 2007). Agriculture is an important sector in terms of economy, employment and trade balance of the BRIC (Brazil, Russia, India and China) economies. The Food and Agriculture Organization of the United Nations (FAO) projects that agricultural production in developing countries will need to be increased by $70 \%$ in order to meet demands by 2050 (FAO, 2009b).

Deforestation generates an estimated additional 17\% of emissions, thus resulting in a total contribution of the so called Land Use, Land-Use Change and Forestry (LULUCF) sector to nearly one third of the current total emissions. For major emerging countries with significant forest resources such Brazil, the LULUCF sector is the major source of emissions. In 2005 deforestation remains the top GHG contributor of Brazilian emissions with a share of nearly 52\% (Cerri et al., 2009). Cerri et al. (2009) also calculated that GHG emissions for the agricultural sector increased by $38 \%$ from 1990 to 2005 , and corresponded to $23 \%$ of 2005 total emissions, i.e. a total contribution of $75 \%$ for the LULUCF sector.

The LULUCF sector is now facing a set of inter-related challenges including providing livelihoods and food for growing populations, improving environmental sustainability, as well as the resilience and productivity of agro-ecosystems, meeting potential demand for bio-energy, including climate change adaptation and mitigation. The highly contentious negotiations surrounding a future LULUCF regime under the UNFCCC in a post-2012 international agreement could have significant impacts in enabling the sector to meet these challenges.

The mitigation potential of the LULUCF sector is high. Many of the technical options are readily available (Bellassen et al., 2010; Bernoux et al., 2006; Cerri et al., 2004, 2007; Henry et al., 2009) and could be deployed immediately: reducing emissions of carbon dioxide $\left(\mathrm{CO}_{2}\right)$ through the reduction of the rate of deforestation and forest degradation, adoption of improved cropland management practices (reduced tillage, integrated nutrient and water management); reducing emissions of methane and nitrous oxide through improved animal production, improved management of livestock waste, more efficient management of irrigation water on rice paddies, improved nutrient management; and, sequestering carbon (C) through conservation farming practices, improved forest management practices, afforestation and reforestation, agroforestry, improved grasslands management and restoration of degraded land. According to the Intergovernmental Panel on Climate Change (IPCC) the total technical mitigation potential of agriculture (considering all gases and sources) is estimated to be in the range 4.5 and $6 \mathrm{Gt} \mathrm{CO}_{2}$-eq per year in 2030 (IPCC, 2007; Smith et al. 2007a, b). Estimates indicate that many of these options are of relatively low cost, or generate significant co-benefits in the form of improved agricultural production systems, resilience and other ecosystem services (Smith et al., 2008).

As $74 \%$ of the agricultural mitigation potential lies in developing countries (Smith et al., 2007b), co-benefits related to rural poverty reduction and food security are of particular importance. Well designed forestry and agriculture development projects/programmes can play an important role in climate change mitigation, either by reducing emissions or by sequestering $\mathrm{C}$. One of the main barriers to implement the potential of agricultural mitigation is the lack of methodologies or approaches that would help project designers and policy makers to integrate significant mitigation effects in agriculture and forestry development projects. The main objective of this study is to describe an easy-to-implement methodology proposed by the FAO to establish ex-ante greenhouse gas balances of agriculture and forestry development programs.

\section{Description of EX-ACT}

EX-ACT (EX-Ante C-balance Tool) is a tool developed by FAO to provide ex-ante measurements of the impact of agriculture and forestry development projects on GHG emissions and $\mathrm{C}$ sequestration, indicating its effects on the C balance. EX-ACT is a land-based accounting system, measuring $\mathrm{C}$ stocks, stock changes per unit of land, and $\mathrm{CH}_{4}$ and $\mathrm{N}_{2} \mathrm{O}$ emissions expressed in $\mathrm{t}$ $\mathrm{ha}^{-1}$ of $\mathrm{CO}_{2}$-eq and $\mathrm{t} \mathrm{yr}^{-1}$ of $\mathrm{CO}_{2}$-eq. The main output of the tool consists of the C-balance resulting from the difference between two scenarios: with and without project options. EX-ACT was designed to work at a project level but it can easily be up-scaled at programme/sector or national levels (Cerri et al., 2010).

Minimum requirements towards quick integration in formulation and planning process - The challenge was to provide a tool that is as simple as possible, as well as cost effective, but at the same time capable of covering the range of projects relevant for the LULUCF sector. To be recognized at the international level this tool must be compliant with international standards and best recognized practices. Moreover the tool should be readily understandable and usable by project developers. Finally, the tool must be upgradable over time, enabling the possibility of incorporating new information and policies, for instance, new approaches for Reducing Emissions from Deforestation and Forest Degradation (REDD) accounting that are currently being debated. Such requirements are preconditions to ensure quick scaling up towards the application of C-balance appraisal on new investment programmes.

Structure of EX-ACT - EX-ACT consists of a set of 18 linked Microsoft Excel sheets into which project designers insert information on dominant soil types and cli- 
matic conditions of the project area together with basic data on land use, land use change and land management practices foreseen under projects activities as compared to a "business as usual" scenario. EX-ACT adopts a modular approach - each "Module" describing a specific land use - and following a three-step logical framework (Figure 1): (i) general description of the project (geographic area, climate and soil characteristics, duration of the project);(ii) identification of changes in land use and technologies foreseen by project components (deforestation, afforestation/reforestation, annual/perennial crops, rice cultivation, grasslands, livestock, inputs, energy); and (iii) computation of the C-balance with and without the project using IPCC default values and when available - ad-hoc coefficients.

Methodologies bebind EX-ACT - The first IPCC Guidelines for National Greenhouse Gas Inventories were published in 1995 and revised in 1996. They consist of three volumes (the reporting instructions, the workbook and the reference manual) each of which provides assistance to the analyst in the preparation of national GHG inventories (Cerri et al., 2009). Nevertheless some inconsistencies in the treatment of Agriculture and Land Use Change and Forestry (LUCF) were present. For instance, the chapter on agriculture covers only $\mathrm{CH}_{4}$ and $\mathrm{N}_{2} \mathrm{O}$ for agricultural soils. Exchanges of $\mathrm{CO}_{2}$ were incorporated in the LULUCF chapter even for agricultural soils (Bernoux et al., 2001). In 2003, the IPCC adopted a "Good Practice Guidance for Land use, Land-use Change and Forestry" (IPCC GPG for LULUCF), and UNFCCC decided that these guidelines should be used by Annex-I Parties (countries with mandatory emission reduction requirements) for preparing and reporting GHG inventories from the LULUCF sector. Non-Annex I Parties (e.g. Brazil) were only encouraged to apply them, as appropriate and to the possible extent, in the preparation of their GHG inventories in their national communications.

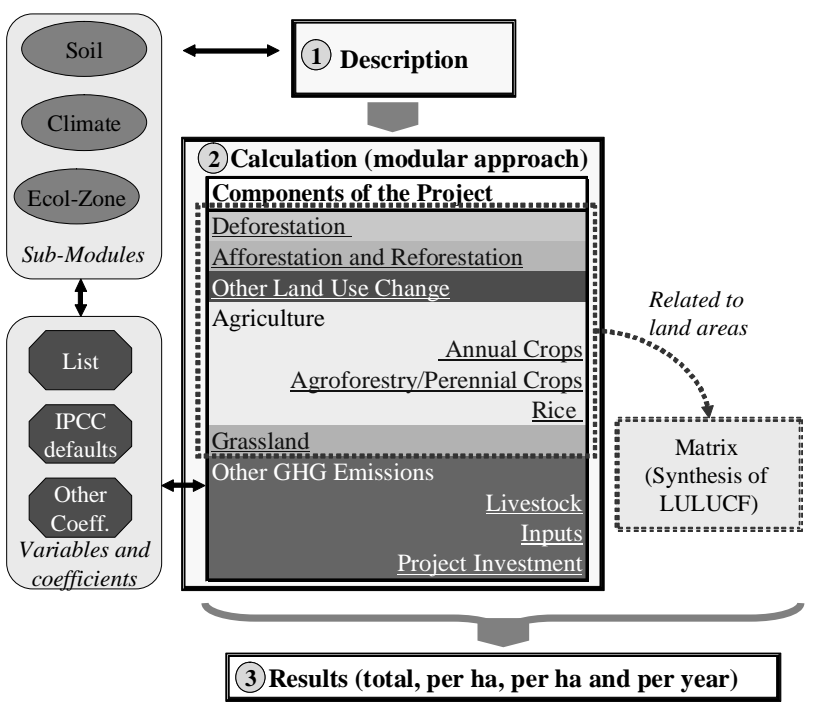

Figure 1 - Schematization of the modular EX-ACT structure.
In the 2003 IPCC (2003) GPG for LULUCF, the land categories are divided into lands remaining in the same land use (for example, forest lands that remain as forest lands) and lands converted into another land-use category (for example, forest lands converted into croplands) during the inventory period. EX-ACT has adopted this approach.

Most of the steps proposed and the provided default coefficients are from the 2006 IPCC guidelines for $\mathrm{Na}$ tional Greenhouse Gas Inventory (Thereafter referred as NGGI-IPCC-2006) and from Chapter 8 of the Fourth Assessment Report from working group III of IPCC (Smith et al., 2007a) for specific mitigation options not covered in NGGI-IPCC-2006. Other required coefficients are from published reviews or international databases. For instance embodied GHG emissions for farm operations, transportation of inputs, and irrigation systems implementation come from Lal (2004) and electricity emission factors are based on data from the International Energy Agency (IEA, www.iea.org). It should be highlighted that EX-ACT also allows users to incorporate their own more specific values when available.

Main concept - In a world where land availability is limited, competition amongst land uses is clearly an important aspect to be taken into account and dealt with in an adequate and comprehensive manner (Riedacker, 2007). Expanding the area of one crop or management practice in one locality is likely to have significant indirect impacts elsewhere. EX-ACT is based on the six broad categories (and sub-categories) proposed for reporting GHG inventories, but is focused mostly on three categories: Forest land, Cropland, Grassland.

Three approaches may be used to represent areas under a specific land use depending on the level of detail of the available information. The tool uses the approach (approach 2) of NGGI-IPCC-2006 that considers information on conversions between categories, but without full spatially-explicit location data. The final result of this approach can be represented as a land-use change matrix between categories.

When performing an ex-ante analysis the user should have an idea on what would happen without the project (i.e. the Business As Usual - BAU - Scenario or as referred to in this document as "Baseline"), thus the final balance is the comparison between the GHG emissions associated with the project compared with the baseline scenario.

The user can define two time periods, one for the implementation phase, i.e. the active phase of the project commonly corresponding to the funding and investment phase, and another for the capitalization phase, i.e. a period where the benefits of the investment are still occurring and may be attributed to the changes induced by the adoption of the project. In Figure 2, the user defines the duration of the implementation (i.e. $t_{1}-t_{2}$ ) and capitalization phases (i.e. $t_{2}-t_{1}$ ), the levels of key variables (hectares converted, stocking rates, amount of in-

Sci. Agric. (Piracicaba, Braz.), v.67, n.1,p.31-40, January/February 2010 
puts...) for the current situation $\left(\mathrm{x}_{0}\right)$, at the end of the implementation phase for the baseline without project $\left(\mathrm{x}_{1}\right)$ or with the project $\left(\mathrm{x}_{2}\right)$.

In terms of dynamics, changes associated with the rate of adoption of new practices or management options occur in the implementation phase. In contrast they are considered as no more change in the capitalization phase. The default assumption for the change is a linear function over time, but advanced users have the possibility to change the dynamic to either an "Immediate" or "exponential" function as shown in Figure 3.

The following example illustrates the impact of the choice of dynamic function on the final result: Given a situation $\left(\mathrm{x}_{0}\right)$ where farmers are using fertilizer on 100 ha of land, and the projected future use over the next 5 years $\left(t_{1}\right)$ is forecasted to increase to 200 ha due to subsidies $\left(\mathrm{x}_{1}\right)$. Under the "immediate" option, the farmers will apply fertilizer on additional 100 ha from the first year of project implementation. In comparison, under the "Linear" dynamic, the growth in area under fertilizer increases progressively by 20 hectares per year. The exponential case represents an intermediary situation. The rate of change is faster at the beginning. The exponential approximation is defined by the equation $\Delta(\mathrm{t})=\Delta_{\text {max }}\left(1-\mathrm{e}^{-\mathrm{kt}}\right)$, with $\Delta_{\text {max }}=\left(\mathrm{x}_{1}-\mathrm{x}_{\mathrm{o}}\right)$, and $\mathrm{k}$ is set in order to have $\Delta\left(\mathrm{t}_{1}\right)=99 \%$ of $\Delta_{\max }$. The immediate scenario corresponds to the maximum attainable change (100\% level), while the linear dynamics corresponds to $50 \%$, and the exponential an intermediary situation set to $78 \%$.

Generic methodologies for estimating carbon pools changes ( $\mathrm{CO}$, balance) - Calculation of changes in $\mathrm{C}$ pools is made using methods that can be applied in a

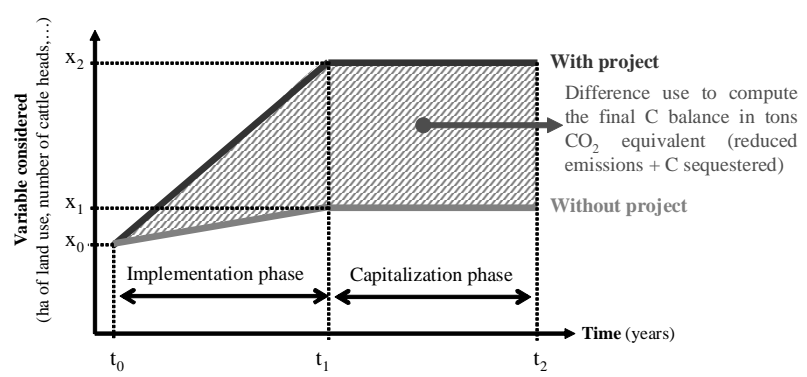

Figure 2 - Schematic representation of how the final balance is calculated with EX-ACT. very similar way for the type of land use change (i.e. generic methods). Generic methodologies are used mainly to account for changes between two categories during conversion, and concerns the five pools defined by IPCC guidelines and UNFCCC: above-ground biomass, below-ground biomass, soil, deadwood and litter. Most calculations, except where specified, use a Tier 1 approach with a stock-difference method for emission of $\mathrm{CO}_{2}$, calculated as the change of $\mathrm{C}$ stocks for the different pools, default values are proposed for each pool of each category (or subcategory or even main vegetation type):

- Above ground biomass: Default values correspond to estimates provided by NGGI-IPCC-2006 and expressed in $\mathrm{t} \mathrm{ha}{ }^{-1}$ of dry matter. The corresponding $\mathrm{C}$ stock (in $\mathrm{t}$ of $\mathrm{C}$ ) is calculated using the specific $\mathrm{C}$ content, e.g. 0.47 for above-ground forest biomass.

- Below ground biomass: In most cases the below-ground biomass is estimated using a ratio (R) of below-ground biomass to above-ground biomass. EX-ACT uses the default values provided by NGGI-IPCC-2006, e.g. $\mathrm{R}$ is 0.37 for all tropical rainforest and 0.27 for Tropical mountain systems. In some cases the total above plus below ground biomass is used if it is not mandatory for calculation to have separate estimates.

- Litter and dead-wood: It is assumed that litter and dead wood pools are zero in all non-forest categories (excluding tree crops and perennial systems) and therefore transitions between non-forest categories involve no C stock changes in these two pools. For other transition default values are provided.

- Soil C: For the soil C estimates, the default values are based on default references for soil organic $\mathrm{C}$ stocks for mineral soils down to a depth of $30 \mathrm{~cm}$. When Soil Organic $\mathrm{C}$ changes over time (land use change or management change), a default time period of 20 years is assumed for transitions between equilibria. These values are found in both IPCC 1997 and 2006 Guidelines, compiled from of a wide range of observations and data from long-term monitoring. Some modules use $\mathrm{C}$ change rates instead of the soil $\mathrm{C}$ stock difference and therefore do not require information on absolute soil C stock. In both approaches it is hypothesized that soil organic C stock changes during the transition to a new equilibrium SOC

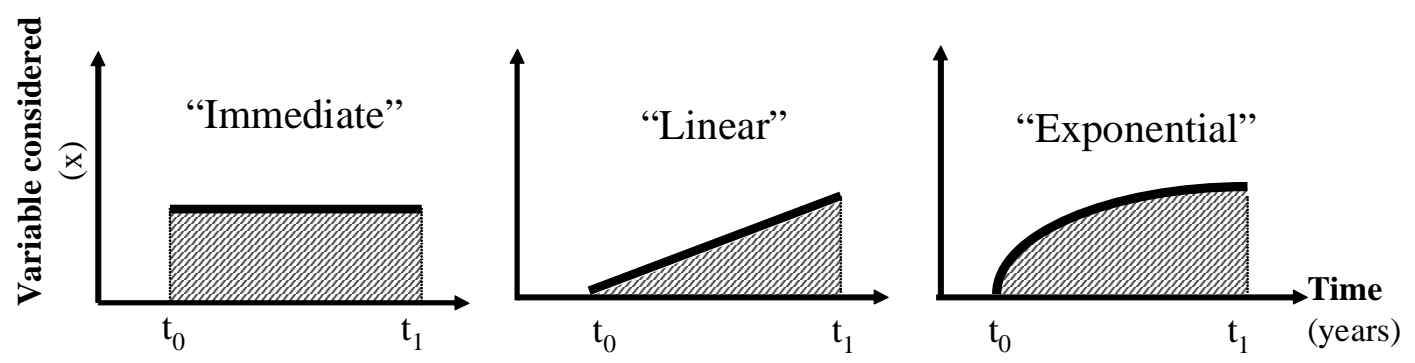

Figure 3 - Schematic representation of the dynamics implemented in EX-ACT. 
occurs with a linear pattern. Although soil $\mathrm{C}$ changes in response to management changes may often be best described by a non linear function, the linear assumption greatly simplifies the methodology and provides a good approximation over a multi-year period.

Generic methodologies for non-CO $\mathrm{CO}_{2} \mathrm{GHG}$ - For $\mathrm{N}_{2} \mathrm{O}$ and $\mathrm{CH}_{4}$ emissions, the generic approach consists of multiplying an emission factor for a specific gas or source category with activity data related to the emission source (e.g. area, animal numbers or mass unit...). Emissions of $\mathrm{N}_{2} \mathrm{O}$ and $\mathrm{CH}_{4}$ are either associated with a specific land use category or subcategory (e.g. $\mathrm{CH}_{4}$ emissions from rice), or are estimated at project aggregated data (e.g. emissions from livestock and $\mathrm{N}_{2} \mathrm{O}$ emission from fertilizers). $\mathrm{CH}_{4}$ and $\mathrm{N}_{2} \mathrm{O}$ emissions are converted into $\mathrm{CO}_{2}$-eq emissions based on the global warming potential of each gas. The user has the ability to use either the official values under the Kyoto Protocol of the UNFCCC, or the last update provided by the IPCC (2007).

Short description of the (sub)modules - Three sub-modules on dominant soil type, climatic characteristics and soil ecological zone allow for more detailed accounting of the project situation in response to individual user needs. The climate module provides external internet links to additional resources useful for determining local or regional climate with greater precision. These resources include a software to download and useful for estimating climate using a database built on 28800 weather stations (LocClim, available at http:// www.fao.org/nr/climpag/pub/en3_051002_en.asp). Three other sub-modules contain the list of variables, the default coefficients for all other modules, plus a specific module for GHG emission factors for electricity by country.

The description module contains a main description of the project boundaries. Users should define the main characteristics of various project components, i.e. dominant soil type, climate, duration of the project indicating both the length of implementation and capitalization phase and location of the project. The user is prompted for information that should either consist of a number or selection of a proposed list of choices. For instance for location, 11 options are available: Africa, Asia (Continental), Asia (Indian subcontinent), Asia (Insular), Middle East, Western Europe, Eastern Europe, Oceania, North America, Central America, and South America. Then the user should select which module to complete according to relevant activities of the project. Table 1 gives an overview of these modules. There are seven land modules and the information provided by the user in terms of surface concerned and variation are synthesized in the matrix module.

The deforestation module can be used to either quantify emissions from deforestation, or for the case of avoided deforestation. For this module, and the afforestation and reforestation module, different types of most probable vegetation are provided with their main characteristics according to the climatic information provided in the description module. For all land related modules, the user should input the main features of the associated land management, e.g. occurrence of burning. For Management Change (MC) Modules (see Table 1) mitigation strategies are proposed for each land management category. The main options available in EX-ACT are those widely accepted and documented in terms of $\mathrm{C}$ change rates (Smith et al., 2007a). These include practices concerning annual crops (e.g. nutrient management, tillage/residue management, irrigation, drainage that increases yields and/or generates higher inputs of $\mathrm{C}$ residue that can lead to increased soil $\mathrm{C}$ storage. It also covers perennial or semi-perennial systems, such as agroforestry and set-aside, and grazing land management. The "rice module" is related to flooded (permanently or part of the year) rice fields. This module covers $\mathrm{CH}_{4}$ emission produced from anaerobic decomposition of organic matter and non- $\mathrm{CO}_{2}$ GHG emissions $\left(\mathrm{CH}_{4}\right.$ and $\mathrm{N}_{2} \mathrm{O}$ ) from biomass burning when occurring. In total, nine rice systems can be built with different water regimes and with corresponding emissions ranging from 0.24 to $2.47 \mathrm{~kg} \mathrm{ha}^{-1} \mathrm{day}^{-1} \mathrm{CH}_{4}$. The grassland module deals with pasture degradation and rehabilitation with or without input management, and also incorporates options for fire occurrence.

Three modules are not specifically land based (in the sense there are not linked exclusively with a determined land area). One is concerned with livestock (and associated manure). An example of its use can be found in Cerri et al. (2010). The second one (inputs) deals with emissions associated with fertilizer inputs and liming. It also includes GHG emissions from production, transportation, storage and transfer of agricultural chemicals using default values proposed by Lal (2004). The last module (investment) is for performing GHG emissions associated with electricity consumption, with fuel consumption (agricultural or forestry machinery, generators...), with installation of irrigation systems and with building of infrastructure. Detailed description of each module will be available in the associated handbook of EX-ACT and available early in 2010 on the FAO web site.

\section{Cases studies}

EX-ACT has been tested on several projects ranging from intensive crop and livestock production to sustainable agriculture, reforestation and rural development. In this section we present two case studies which are relevant to show the potential of EX-ACT to indicate projects effects on the C-balance: the "Accelerated Food Security Project" in Tanzania and the "Rio Rural Project" in Brazil.

An example from the "Accelerated Food Security Project" in Tanzania - The case of the FAO/World Bank "Accelerated Food Security Project" (ASFP) in Tanzania represents an interesting example of the po- 
Table 1 - Overview of Modules used for C-Balance calculation.

\begin{tabular}{|c|c|c|c|c|c|}
\hline $\begin{array}{l}\text { Name of the } \\
\text { Module }\end{array}$ & $\begin{array}{l}\text { Main } \\
\text { category }\end{array}$ & IPCC-category & GHG concerned & $\begin{array}{l}\text { Link with } \\
\text { other Land- } \\
\text { related Module }\end{array}$ & Main methodologies and references \\
\hline Deforestation & $\mathrm{LUC}^{1}$ & $\begin{array}{l}\text { Land converted to } \\
\text { another land-use: } \\
\text { Forestland to land }\end{array}$ & $\begin{array}{l}\text { Mostly } \mathrm{CO}_{2} \text {, but also } \\
\mathrm{CH}_{4}^{*} \text { and } \mathrm{N}_{2} \mathrm{O} *\end{array}$ & $\begin{array}{l}\text { MC Modules } \\
\text { and Matrix }\end{array}$ & $\begin{array}{l}\text { Volume } 4 \text { (Chapter } 4 \text { ) of NGGI } \\
\text { (IPCC, 2006) }\end{array}$ \\
\hline $\begin{array}{l}\text { Afforestation } \\
\text { and } \\
\text { Reforestation }\end{array}$ & LUC & $\begin{array}{l}\text { Land converted to } \\
\text { another land-use: land } \\
\text { to Forestland }\end{array}$ & $\begin{array}{l}\text { Mostly } \mathrm{CO}_{2} \text {, but also } \\
\mathrm{CH}_{4}^{*} \text { and } \mathrm{N}_{2} \mathrm{O}^{*}\end{array}$ & $\begin{array}{l}\text { MC Modules } \\
\text { and Matrix }\end{array}$ & $\begin{array}{l}\text { Volume } 4 \text { (Chapter } 4 \text { ) of NGGI } \\
\text { (IPCC, 2006) }\end{array}$ \\
\hline $\begin{array}{l}\text { Other Land Use } \\
\text { Change }\end{array}$ & LUC & $\begin{array}{l}\text { Land converted to } \\
\text { another land-use: } \\
\text { non-Forestland to } \\
\text { another non- } \\
\text { Forestland }\end{array}$ & $\mathrm{CO}_{2}$ & $\begin{array}{l}\text { MC Modules } \\
\text { and Matrix }\end{array}$ & $\begin{array}{l}\text { Volume } 4 \text { (Chapters 4-6) of NGGI } \\
\text { (IPCC, 2006) }\end{array}$ \\
\hline Annual Crops & $\mathrm{MC}^{2}$ & $\begin{array}{l}\text { Cropland remaining } \\
\text { Cropland }\end{array}$ & $\begin{array}{l}\text { Mostly } \mathrm{CO}_{2} \text {, but also } \\
\mathrm{CH}_{4}^{*} \text { and } \mathrm{N}_{2} \mathrm{O}^{*}\end{array}$ & Matrix & $\begin{array}{l}\text { Volume "Mitigation" (Chapter 8) of } \\
\text { the fourth Assessment Report of } \\
\text { the IPCC (Smith et al., 2007a) }\end{array}$ \\
\hline $\begin{array}{l}\text { Agroforestry / } \\
\text { Perennial Crops }\end{array}$ & MC & $\begin{array}{l}\text { Cropland remaining } \\
\text { Cropland }\end{array}$ & $\begin{array}{l}\text { Mostly } \mathrm{CO}_{2} \text {, but also } \\
\mathrm{CH}_{4}^{*} \text { and } \mathrm{N}_{2} \mathrm{O}^{*}\end{array}$ & Matrix & $\begin{array}{l}\text { Volume "Mitigation" (Chapter 8) of } \\
\text { the fourth Assessment Report of } \\
\text { the IPCC (Smith et al., 2007a) }\end{array}$ \\
\hline Rice & MC & $\begin{array}{l}\text { Cropland remaining } \\
\text { Cropland }\end{array}$ & $\begin{array}{c}\text { Mostly } \mathrm{CH}_{4} \text {, but also } \\
\mathrm{N}_{2} \mathrm{O}^{*}\end{array}$ & Matrix & $\begin{array}{l}\text { Volume } 4 \text { (Chapter 5) of NGGI } \\
\text { (IPCC, 2006) }\end{array}$ \\
\hline Grassland & MC & $\begin{array}{l}\text { Grassland remaining } \\
\text { Grassland }\end{array}$ & $\begin{array}{l}\text { Mostly } \mathrm{CO}_{2} \text {, but also } \\
\mathrm{CH}_{4}^{*} \text { and } \mathrm{N}_{2} \mathrm{O}^{*}\end{array}$ & Matrix & $\begin{array}{l}\text { Volume } 4 \text { (Chapter 6) of NGGI } \\
\text { (IPCC, 2006) }\end{array}$ \\
\hline Livestock & & $\begin{array}{l}\text { Not a land use } \\
\text { category }\end{array}$ & $\mathrm{CH}_{4}$ and $\mathrm{N}_{2} \mathrm{O}$ & & $\begin{array}{l}\text { Volume } 4 \text { (Chapter 10) of NGGI } \\
\text { (IPCC, 2006) and Volume } \\
\text { "Mitigation" (Chapter 8) of the } \\
\text { fourth Assessment Report of the } \\
\text { IPCC (Smith et al., 2007a) }\end{array}$ \\
\hline Inputs & & $\begin{array}{l}\text { Not a land use } \\
\text { category }\end{array}$ & $\mathrm{CO}_{2}$ and $\mathrm{N}_{2} \mathrm{O}$ & & $\begin{array}{l}\text { Volume } 4 \text { (Chapter 11) of NGGI } \\
\text { (IPCC, 2006) and Lal (2004) }\end{array}$ \\
\hline $\begin{array}{l}\text { Project } \\
\text { Investment }\end{array}$ & & $\begin{array}{l}\text { Not a land use } \\
\text { category }\end{array}$ & $\mathrm{CO}_{2}$ & & $\begin{array}{l}\text { Volume } 1 \text { of NGGI (IPCC, 2006), } \\
\text { Lal (2004) and U.S. Department of } \\
\text { Energy (2007) }\end{array}$ \\
\hline
\end{tabular}

${ }^{1} \mathrm{LUC}=$ Land_Use Change, ${ }^{2} \mathrm{MC}=$ Management Change, ${ }^{*}$ from biomass burning (Chapter 2 of NGGI - IPCC, 2006), ${ }^{3}$ NGGI $=$ Guidelines for National Greenhouse Gas Inventories.

tential use of Ex-Act in estimating the impact of agricultural development projects on GHG emissions and C sequestration. The ASFP seeks to increase maize and rice production and productivity in targeted areas mainly by improving farmers access to critical agricultural inputs like fertilizers and improved seeds. Maize and rice production accounts respectively to 25 and $14 \%$ of agricultural GDP. Thus, improvements in food crop productivity will greatly contribute to the overall economic growth and poverty reduction in Tanzania.

Current productivity of maize and rice farmers in Tanzania is very low (e.g. in 2007/08 average maize yield was only $1.3 \mathrm{t} \mathrm{ha}^{-1}$, much lower than in most neighbouring countries). The limited use of improved seeds and fertilizers has been the major reason of these low yields. In 2005/06, for example, the rate of fertilizer application in the country was reported at $8 \mathrm{~kg} \mathrm{ha}^{-1} \mathrm{~N}$ while the depletion of soil nutrients was found to be about $61 \mathrm{~kg} \mathrm{ha}^{-1} \mathrm{~N}$ (IFPRI, 2008). The use of improved seeds is also extremely low (only $24 \%$ of farmers, ranging from $15 \%$ in the South to $45 \%$ in the North), and the seeds planted are mainly self-produced and recycled (IFPRI, 2008).

Farmers participating in the project obtain, for an average of 0.5 hectare of maize/rice cropped area, an input package through the National Agricultural Input Voucher Scheme (NAIVS), consisting of one voucher for Nitrogen fertilizer (1 bag, i.e. $50 \mathrm{~kg}$ ) Urea, one voucher for Phosphorus fertilizer (1 bag of diammonium phosphate - DAP - which is the most commonly used basal fertilizer in Tanzania) and one seed voucher $(10 \mathrm{~kg}$ of open-pollinated varieties or hybrid maize and rice seeds). Participating farmers are also requested to abandon the practice of burning crop residues.

At full implementation the project is expected to benefit 2.5 million smallholders in several districts of Tanzania. The aim of NAIVS is to intensify food production in areas with high agro-ecological potential for pro- 
ducing staple crops in the southern and northern highlands as well as western regions: the southern highlands have the largest maize production zones in Tanzania (the four regions Mbeya, Rukwa, Ruvuma and Iringa account for more than $40 \%$ of the country's maize production), while rice production is more evenly distributed over the country. Project implementation will determine the adoption of improved cropland practices on most maize and rice cropland. It is expected that current land uses remain unchanged in the "without project" scenario, while "with project" around $70 \%$ of targeted area will adopt improved cropland management practices for both crops. The following table describes the current land use and the two alternative scenarios ("with" and "without project").

Conventional maize production makes use of farmsaved and recycled seeds without any nutrient management practices and the practice of incorporating crop residues is generally not adopted, while, there are two main types of rice production systems in the project area: rainfed lowland, often flooded (with non flooded preseason longer than 180 days); and irrigated, continuously flooded, with a flooded preseason longer than 30 days. Improved cropland management practices will consist of incorporating crop residues into soils, using improved seed varieties and implementing a nutrient management plan. Specifically, the following rates of fertilization will be adopted both on maize and rice fields: $0.1 \mathrm{t} \mathrm{ha}^{-1} \mathrm{yr}^{-1}$ of Urea; $0.018 \mathrm{t} \mathrm{ha}^{-1} \mathrm{yr}^{-1}$ of $\mathrm{N}$ synthetic fertilizer and 0.046 $\mathrm{t} \mathrm{ha} \mathrm{a}^{-1} \mathrm{yr}^{-1}$ of phosphorus synthetic fertilizer. Given the cropland area estimated in the "with project" scenario, overall rates of fertilizer with project correspond at the end of the implementation phase to $83,820 \mathrm{t} \mathrm{yr}^{-1}$ of urea,

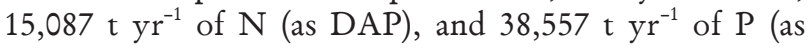
DAP).

The impact of project activities on the overall C balance has been estimated using the modules called Annual, Rice and Inputs of the EX-ACT tool. The latter computed $\mathrm{CO}_{2}$ emissions from urea applications together with the $\mathrm{CO}_{2}$-eq emissions from production, transportation, storage and transfer of agricultural chemicals (phosphorus and nitrogen synthetic fertilizers, i.e. DAP). The increase in soil organic content due to the adoption of improved crop management practices is taken into account in the module Annual, while the specific module on rice estimated the effects on the $\mathrm{C}$ balance of improved rice management practices. Results show that annual crops with project compared to without project result in a net sink of 11.25 $\mathrm{Mt} \mathrm{CO}_{2}$-eq, although expanded fertilizer use and changes in rice management are net sources of respectively $1.6 \mathrm{Mt} \mathrm{CO}_{2}$-eq and 2.4 $\mathrm{Mt} \mathrm{CO}_{2}$-eq. The adoption of improved land and integrated nutrient management practices will contribute to soil $\mathrm{C}$ sequestration so that the net project effect will be the creation of a C sink, with positive effects in terms of mitigation. The overall $\mathrm{C}$ balance of the ASFP of Tanzania is computed as a difference between $\mathrm{C}$ sinks and sources and it has been estimated at $7.2 \mathrm{Mt} \mathrm{CO}_{2}$-eq over 20 years, corresponding to $350,000 \mathrm{t} \mathrm{yr}^{-1}$ of $\mathrm{CO}_{2}-$ eq Given the area of $1.06 \mathrm{Mha}$, this corresponds to a sequestration rate of $0.3 \mathrm{t} \mathrm{ha}^{-1} \mathrm{yr}^{-1}$ of $\mathrm{CO}_{2}$-eq. As expected, the most significant source of mitigation comes from the implementation of improved cropland management in maize production.

The case of the "Rio Rural Project" in Brazil - Ex-Act can be applied to more complex projects such as the GEF/World Bank "Rio Rural Project" in Brazil, aimed at promoting sustainable rural development in North and Central Rio de Janeiro State to cope with the ongoing land erosion and its adverse effects on rural economy. The project supports a broad set of activities and its implementation is based on an integrative approach of the agro-silvo-pastoralist systems, based on hydrographical micro-catchments as planning units. This section describes the application of EX-ACT to some project components identified as having a significant impact on the $\mathrm{C}$ balance and for which data were available. The case also represents an interesting example of the potential of using the tool during the project design phase.

EX-ACT has been used to estimate the GHG impact of the following components of the project: (i) Protection of springs and streams; (ii) Protection of the legal reserves; (iii) Promotion of sustainable cropping patterns: reduced tillage, contour/strip cropping, inter-cropping, mulching, improve water management, use of green manure and organic fertilizer; (iv) Pasture management: pasture rotations and production of sugarcane

Table 2 - Land use systems corresponding to the current situation and the two alternative scenarios ("with" and "without project") for the FAO/World Bank "Accelerated Food Security Project” (ASFP) in Tanzania.

\begin{tabular}{lccc}
\hline Land use & Current situation & Without project & With project \\
\hline & 972.6 & 972.6 & 260.1 \\
Maize conventional technology & 0 & 0 & 712.5 \\
Maize improved technology & 62.9 & 62.9 & 18.9 \\
Rice rainfed conventional technology & 22.9 & 22.9 & 6.9 \\
Rice irrigated conventional technology & 0 & 0 & 44.0 \\
Rice rainfed improved technology & 0 & 0 & 16.1 \\
Rice irrigated improved technology & & & \\
\hline
\end{tabular}


forage; (v) Increased use of lime and fertilizers; (vi) Promotion of small agro-industry: construction of warehouse and packing house, installation of cooling systems and; (vii) Improvement of infrastructure: construction of sanitations and roads. Table 3 presents how each component is taken into account in the EX-ACT simulation when data were available.

The results of the EX-ACT simulations are reported here, showing the GHG impact of each module and the overall effect of the project on the C balance (Figure 4).

All the land-based activities supported by the project contribute to create a $\mathrm{C}$ sink totalling 564,399 t $\mathrm{CO}_{2}$-eq after 20 years, the only source arising from construction of infrastructure $\left(9,930 \mathrm{t} \mathrm{CO}_{2}\right.$-eq after 20 years). Overall, the net effect on the $\mathrm{C}$ balance of the project components taken into account amounts to over 550,000 $\mathrm{t} \mathrm{CO}_{2}^{-}$ eq. However, this result needs to be interpreted with caution since other project components which are likely to impact negatively on the $\mathrm{C}$ balance were not taken into account at this stage due to a lack of data. For example, the project is expected to increase the use of lime and fertilizers and to promote road construction. Also, extension activities (400 technicians are expected to work extensively in the area) needed to implement the project and promote the adoption of sustainable land management practices will increase GHG emissions because of the increase in fuel consumption. The case is also interesting to show that, if used at an early stage, EX-ACT provides an interesting planning tool to mainstream climate change mitigation considerations into agricultural and rural development projects, allowing project designers to simulate different scenarios and to analyze the relative impact on $\mathrm{C}$ balance. For example, project designers for the Rio Rural Project are currently testing the impact on C balance of three different scenarios of fuel consumption, depending on the type of fuel used: $100 \%$ gasoline, $20 \%$ ethanol in gasoline, and 100\% ethanol technologies.

Table 3 - Description of the components and Module concerned in EX-ACT with information regarding the systems considered and their extent for the GEF/World Bank "Rio Rural Project" in Brazil.

\begin{tabular}{|c|c|c|c|c|c|c|}
\hline \multirow[b]{2}{*}{ Project Component } & \multirow{2}{*}{\multicolumn{2}{|c|}{ EX-ACT module(s) concerned }} & \multirow[b]{2}{*}{ Unit } & \multicolumn{3}{|c|}{ Area concerned } \\
\hline & & & & $\begin{array}{r}\text { Current } \\
\text { situation }\end{array}$ & $\begin{array}{l}\text { Without } \\
\text { Project }\end{array}$ & $\begin{array}{l}\text { With } \\
\text { Project }\end{array}$ \\
\hline \multirow{3}{*}{$\begin{array}{l}\text { Protection of spring and } \\
\text { streams } \\
\text { Protection of the legal } \\
\text { reserve }\end{array}$} & Deforestation & & ha & $<1$ & 0 & $<1$ \\
\hline & Afforestation/Reforestation & & ha & 0 & 0 & 850 \\
\hline & Grassland & & ha & 850 & 850 & 0 \\
\hline \multirow{2}{*}{$\begin{array}{l}\text { Promotion of sustainable } \\
\text { cropping patterns }\end{array}$} & Annual crops: & Current systems & ha & 226,070 & 225,104 & 220,994 \\
\hline & & Improved systems & ha & 0 & 966 & 5,076 \\
\hline \multirow{3}{*}{ Pasture management } & Grassland: & Moderately degraded & ha & 691 & 585 & 0 \\
\hline & & Non degraded & ha & 0 & 85 & 290 \\
\hline & $\begin{array}{l}\text { Improved w/ inputs } \\
\text { management }\end{array}$ & & ha & 0 & 21 & 401 \\
\hline $\begin{array}{l}\text { Promotion of small agro- } \\
\text { industry Improvement of } \\
\text { infrastructure (sanitations) }\end{array}$ & $\begin{array}{l}\text { Investment (Construction } \\
\text { of infrastructures) }\end{array}$ & & $\mathrm{m}^{2}$ & 0 & 13,900 & 31,720 \\
\hline
\end{tabular}

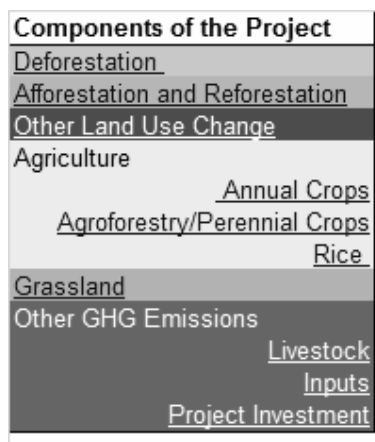

Positive value $=$ Source of GHG Negative value $=$ Sink of GHG

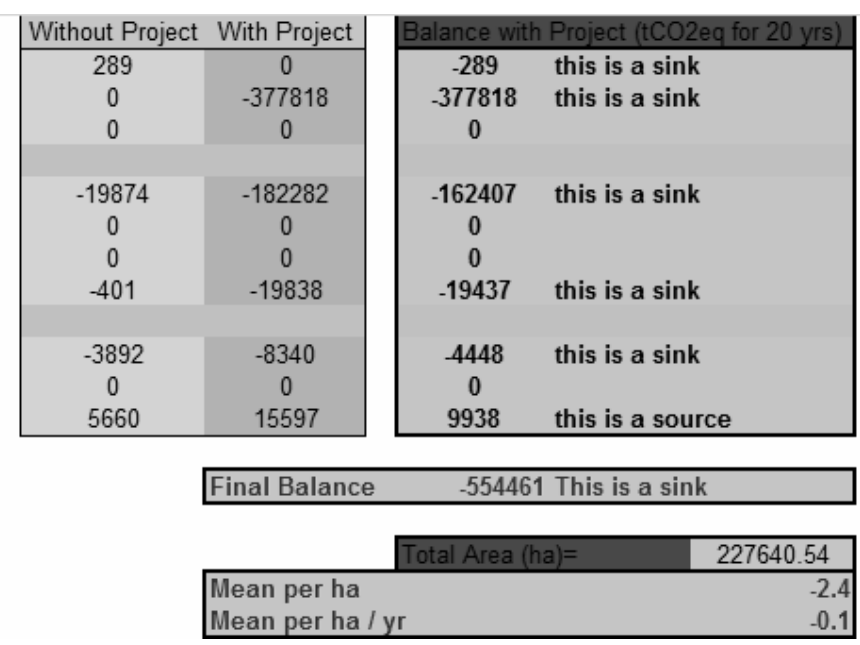

Figure 4 - Facsimile of the results as exhibited in EX-ACT. 


\section{The way forward}

Agricultural systems can contribute significantly to an overall mitigation that will help to reduce the extent of adaptation required and catastrophic impacts on systems and sectors, on which lives and livelihoods depend. Many agricultural mitigation options, particularly those that involve soil $\mathrm{C}$ sequestration also generate co-benefits for adaptation, food security and rural development. These agricultural mitigation options can be pursued in the context of, and without adverse affects to, national sustainable development processes. Mitigation benefits from agriculture could generate an additional financing stream to support such developments through the implementation of payment for environmental service programs (PES), or potentially through international agreements on mitigation financing for developing countries currently under negotiation in the UNFCCC.

Until now there has been no user-friendly tool to allow for a quick appraisal of the potential mitigation impacts of agricultural investment projects. EX-ACT allows for the C-balance appraisal of new investment programmes by ensuring an appropriate method available to donors and planning officers, project designers, and decision makers within agriculture and forestry sectors in developing countries. The tool can also help to identify the mitigation impacts of various investment project options and thus provide an additional criterion for consideration in project selection.

EX-ACT has gone through a field-testing program in 2009 and a peer-review process is ongoing. The Beta version will be release and available on the web early 2010 for use by project designers in international organizations and donor agencies working on agriculture (and forestry) development and/or involved in agriculture (and forestry) investment projects. The tool will then be available for free use by donors and technical partners. However appropriate training, software updating and technical quality monitoring framework will have to be in place to support effective implementation. After an initial phase of use at the project and program level, the tool will also be modified and tested for use in the development of national sector strategies and policies (e.g. to compute the $\mathrm{C}$ balance of aggregated agriculture sector strategies and policy options) or for regional initiatives.

\section{References}

Bellassen, V.; Manlay, R.; Chéry, J.P.; Gitz, V.; Touré, A.; Bernoux, M.; Chotte, J.L. 2010. Multi-criteria spatialization of soil organic carbon sequestration potential from agricultural intensification in Senegal. Climatic Change 98: 213-243.

Bernoux, M.; Carvalho, M.C.S.; Volkoff, B.; Cerri, C.C. 2001. CO emission from mineral soils following land-cover change in Brazil. Global Change Biology 7: 779-787.

Bernoux, M.; Cerri, C.C.; Cerri, C.E.P.; Siqueira Neto, M.; Metay, A.; Perrin, A.S.; Scopel, E.; Razafimbelo, T.; Blavet, D.; Piccolo, M.C.; Pavei, M.; Milne, E. 2006. Cropping systems, carbon sequestration and erosion in Brazil, a review. Agronomy for Sustainable Development 26: 1-8.
Cerri, C.C.; Bernoux, M.; Cerri, C.E.P., Feller, C. 2004. Carbon cycling and sequestration opportunities in South America: The case of Brazil. Soil Use and Management 20: 248-254.

Cerri, C.E.P.; Sparovek, G.; Bernoux, M.; Easterling, W.E.; Melillo, J.M.; Cerri, C.C. 2007. Tropical agriculture and global warming: impacts and mitigation options. Scientia Agricola 64: 83-89.

Cerri, C.C.; Maia, S.M.F.; Galdos, M.V.; Cerri, C.E.P.; Feigl, B.J.; Bernoux, M. 2009. Brazilian greenhouse gas emissions: the importance of agriculture and livestock. Scientia Agricola 66: 831-843.

Cerri, C.C.; Bernoux, M.; Maia, S.M.F.; Cerri, C.E.P.; Costa Junior, C.; Feigl, B.J.; Frazão, L.A.; Mello, F.F.C.; Galdos, M.V.; Moreira, C.S.; Carvalho J.L.N. 2010. Greenhouse gas mitigation options in Brazil for land-use change, livestock and agriculture. Scientia Agricola 67: 102-116.

Food and Agriculture Organization [FAO]. 2009a. FaoStat. Available at http://faostat.fao.org [Accessed Dec. 14, 2009]

Food and Agriculture Organization [FAO]. 2009b. How to Feed the World in 2050. FAO, Roma, IT. p.36.

Henry, M.; Tittonell, P.; Manlay, R.; Bernoux, M.; Albrecht, A.; Vanlauwe, B. 2009. Biodiversity, carbon stocks and sequestration potential in aboveground biomass in smallholder farming systems of western Kenya. Agriculture Ecosystems and Environment 129: 238-252.

International Food Policy Research Institute [IFPRI]. 2008. Determinants of Productivity and Commercialization of the Staple Food Crops and Their Demand Trend in Tanzania: Evidence from the 2002/03 Agricultural Census Survey. IFPRI, Washington, DC. USA.

International Labour Organization [ILO]. 2007. Key Indicators of the Labour Market (KILM), 5.ed. . ILO, Geneva, CH.

Intergovernmental Panel on Climate Change [IPCC]. 1997. Revised 1996 IPCC Guidelines for National Greenhouse Gas Inventories: Intergovernmental Panel on Climate Change. United Nations Environment Programme/ International Energy Agency, Paris, FR. 3v.

Intergovernmental Panel on Climate Change [IPCC]. 2003. Good Practice Guidance for Land Use, Land-Use Change and Forestry. IPCC/OECD/IEA/IGES, Hayama, JP.

Intergovernmental Panel on Climate Change [IPCC]. 2006. IPCC Guidelines for National Greenhouse Gas Inventories, In: Eggleston, H.S.; Buendia, L.; Miwa, K.; Ngara, T.; Tanabe, K., eds. 2006. Agriculture, Forestry and Other Land Use. IGES, JP. vol.4

Intergovernmental Panel on Climate Change [IPCC]. 2007. Intergovernmental Panel on Climate Change, United Nations Environment Programme. Assessment Report 4. Contribution of Working Groups I, II and III to the Fourth Assessment Report of the Intergovernmental Panel on Climate Change. IPPC, Geneva, CH.

Lal, R. 2004. Carbon emission from farm operations. Environment International 30: 981-990.

Riedacker, A. 2007. A global land use and biomass approach to reduce greenhouse gas emissions, fossil fuel use and to preserve biodiversity. Fondazione Eni Enrico Mattei, Milan, IT. (Working Papers, 121). Available at http://www.bepress.com/ feem/paper121 [Accessed Dec. 14, 2009]

Smith, P.; Martino, D.; Cai, Z.; Gwary, D.; Janzen, H.H.; Kumar, P.; McCarl, B.; Ogle, S.; O’Mara, F.; Rice, C.; Scholes, R.J.; Sirotenko, O. 2007a. Agriculture. In: (Metz, B.; Davidson, O.R.; Bosch, P.R.; Dave, R.; Meyer, A., eds. Climate Change 2007: Mitigation. Contribution of Working Group III to the Fourth Assessment Report of the Intergovernmental Panel on Climate Change. Cambridge University Press, New York, NY, USA.

Smith, P.; Martino, D.; Cai, Z.; Gwary, D.; Janzen, H.H.; Kumar, P.; McCarl, B.; Ogle, S.; O’Mara, F.; Rice, C.; Scholes, R.J.; Sirotenko, O.; Howden, M.; Mcallister, T.; Pan, G.; Romanenkov, V.; Schneider, U.; Towprayoon, S. 2007b. Policy and Technological constraints to implementation of greenhouse gas mitigation options in agriculture. Agriculture Ecosystem Environment 118: 6-28. 
Smith, P.; Martino, D.; Cai, Z.; Gwary, D.; Janzen, H.H.; Kumar, P.; McCarl, B.; Ogle, S.; O’Mara, F.; Rice, C.; Scholes, R.J.; Sirotenko, O.; Howden, M.; McAllister, T.; Pan, G.; Romanenkov, V.; Schneider, U.; Towprayoon, S.; Wattenbach, M.; Smith, J.U. 2008. Greenhouse gas mitigation in agriculture. Philosophical Transactions of the Royal Society B 363: 789-813.

United Nation Framework Convention on Climate Change [UNFCCC]. 2008. Challenges and Opportunities for Mitigation in the Agricultural Sector. UNFCCC, Bonn, DE. (Document FCCC/TP/2008/8). 101p.
U.S. Department of Energy. [USDE]. 2007. Appendix F. Electricity Emission Factors, Voluntary Reporting of Greenhouse Gases. USDE, Washington DC, USA. (Form EIA-1605). Available at h t t p : / / w w w.eia.doe.gov/oiaf/1605/pdf/ Appendix\%20F_r071023.pdf [Accessed Dec. 14, 2009]

Received October 16, 2009

Accepted December 18, 2009 